\title{
The Adaptation Strategy of Semarangan Dance Style's Learning Method in UNNES during Covid-19 Pandemic Era
}

\author{
Lesa Paranti ${ }^{1}$, Dhoni Zustiyantoro ${ }^{2}$, Khoirunnisa Kumala ${ }^{3}$ \\ \{lesa_tari@mail.unnes.ac.id ${ }^{1}$, petanikata@mail.unne.ac.id ${ }^{2}$, khoirunnisakumala11@ mail.unnes.ac.id ${ }^{3}$ \} \\ Department of Drama, Dance, and Music Education, Universitas Negeri Semarang, Indonesia ${ }^{1}$, \\ Department of Javanese Language and Literature Education, Universitas Negeri Semarang, Indonesia ${ }^{2}$, \\ Department of Drama, Dance, and Music Education, Universitas Negeri Semarang, Indonesia ${ }^{3}$
}

\begin{abstract}
This study aimed to analyze the adaptation strategy of Semarangan dance style's learning method in Universitas Negeri Semarang during the pandemic. This study uses qualitative and quantitative methods. The data collections were interview, observation, documentation techniques, and literature review. Triangulation used as the data validity test. The result shows that lecturer and students have adapted with the situations. The lecturer uses virtual collaborative learning method by optimizing the use of ICT. The lecturer shares instructional videos as a media that helps students to learn. There are opportunities and obstacles in implementing online learning especially in the dance learning. Online learning makes students practice the dance independently. It is also not limited by distance and time. Semarangan dance style's learning has several distinctive motion techniques, so the difficulty is in giving feedback to students directly because the lecturer couldn't touch the body parts that need to be fixed with certain techniques.
\end{abstract}

Keywords: Semarangan dance, learning method, ICT

\section{Introduction}

Indonesia has various traditional dances as one of the cultural heritage that needs to be preserved as an effort to empower national identity. One of the agents that plays role in the preservation of these traditional dances are universities. Universitas Negeri Semarang has an Aaccredited Department of Drama, Dance, and Music Education. As the university which results prospective dance educators who are professional, discourse and the future needs have to be noticed for the students' provisions. The dance learning will run effectively when the learning method used is in accordance with the characteristics of material and resources.

Learning method is a systematic way done by the educators in the delivery of material. Educators need to master various learning methods so that students can easily absorb the material and be enthusiastic about learning. The selection of learning methods needs to pay attention to the learning goals (stated in the learning plan), learning models, students' characteristics, learning materials, time, and infrastructures. Several types of dance learning methods that are widely practiced include lectures, question and answer method, discussions, demonstrations, drills, experiments, and team teaching method [1].

The right dance learning method will affect students' ability to absorb and explore their potential for the better [2]. Classroom learning must pay attention to the characteristics of the material and the abilities of the students. Students have different initial potentials as well as the 
ability to absorb different materials. Dance learning should be process-oriented, so that students' learning progress can be noticed. A dance lecturer must have the ability to implement both dance and pedagogy. According to Huddy, this dual role is called "The Teaching Artist" [3].

The ideal condition of dance learning suddenly changes due to the outbreak of Corona virus that hits various countries in the world including Indonesia since February 2020. The government, especially the Ministry of Education and Culture decided that learning should be done online at home, and so with the dance learning activities in the Dance Education Study Program, UNNES. Therefore, lecturers are required to quickly adapt to the online learning models. Online learning requires collaboration of appropriate learning methods. Educators need to master ICT (Information Communication Technology) as a tool in online learning. When viewed from the students' point of view, technology provides opportunities to motivate students in learning and has a collaborative nuance [4]. However, these opportunities can be a threat when students have difficulty in accessing the internet or have limited facility. Nevertheless, education in universities needs to continue to improve accessibility to the realm of technology [5]. The use of ICT in universities' teaching is considered as a must in adapting to the new situation.

The Department of Drama, Dance, and Music especially the Dance Education study program manages to maximize online learning. The types of courses in this study program include practical and theoretical subjects. One of the practical courses that students have been waiting for is Tari Pesisiran Jawa Tengah I (Central Java Coastal Dance Course I). This course is a characteristic of the study program because the material taught is regional dances of Central Java such as the Semarangan dance. Semarangan dance learning in the $3^{\text {rd }}$ week of 2019/2020 odd semester lecture was conducted online according to the rector's appeal. Lecturers and students try to adapt to the technology. The strength of online learning is that it is participative while dance is also a participative activity which requires physical presence. Technological advances have created opportunities for dance educators to consider appropriate learning methods [6]. Learning dance practice online requires specific strategies and methods to achieve its goal. The research urgency of dance learning methods is carried out because of the Covid19 outbreak which requires lecturers to be able to adapt. The lecturers must be active and creative in using the right method by utilizing various online learning applications. Based on the insights and experiences of lecturer and students in Semarangan dance learning, the results of this research contribute as reflection and input for the implementation of traditional dance learning in universities as home of the civilization development science.

\section{Method}

Based on the problems identified, the type of research used is a mixed method research. Mixed method is the development of a research type that combines qualitative and quantitative research characteristics. Usually used in social science research to help reinforce a more comprehensive evidence and perspective [7]. The researchers use this method because in this research, the researchers need to describe adaptation strategy which is done by the lecturer in implementing Semarangan dance learning method in the middle of the outbreak. The authors also need to find out students' responses to the method that is being implemented through the questionnaire (quantitative data). Qualitative research is used in describing adaptation strategy in Semarangan dance learning method. Qualitative research is a type of research aims to understand what is experienced by research subjects, such as behavior, perception, motivation, 
action, etc. holistically and descriptively in the form of words and language in a natural context [8]. Quantitative research is used as a tool in retrieving data in the form of students' responses in one class. Researchers took the data through observation, interview, documentation, and questionnaire.

Observation was made online by joining the Google Classroom in Tari Pesisiran Jawa Tengah I (Central Java Coastal Dance Course I) class. Researchers could observe the interactions that occur in the Google Classroom and the methods used by the lecturer. Interview was conducted directly with Mr. Bintang as the lecturer. Documentation was done virtually using researchers' documentation and research documentation. The authors used questionnaires created with Google form and distributed them to students who have taken Denok dance material through the WhatsApp group. There were fifteen respondents who gave their responses to the application of the learning methods that have been carried out. Data from the observation, interview and documentation was followed by students' responses data through questionnaires. Triangulation model was used in the data analysis.

\section{Result and Discussion}

\subsection{Semarangan Dance Style}

The emergence of Semarangan dance begins with the presence of Gambang Semarang. It is a performance art which combines music, dance, sound art, and comedy [9]. The research from Tristiani and Lanjari showed that dance form in Gambang Semarang performing art does not have particular performance pattern, but it contains various distinctive motions such as ngeyek, ngondhek, and genjot [10]. This study supports data about the form of Semarangan dance style. In its journey, a dance development based on cultural characteristics of Semarang has emerged and is developed by several artists and art academics. The development of Semarangan dance is caused by the creativity of several artists and art academics and the government support. Some of the dances are Gado-Gado Semarang dance, Denok dance, Warak Dhugder dance, Geyol Denok dance, etc.

One of UNNES lecturers who plays role in the development of Semarangan dance is Drs. Bintang Hanggoro Putra, M.Hum. The dance is called Denok dance. The dance expresses the agility of Semarang young women which is expressed through the agile and dynamic motions. The name "Denok" is taken from the term "nok" which is a term to address young women in Semarang. Currently, Denok dance is being one of the learning materials in Tari Pesisiran Jawa Tengah I (Central Java Coastal Dance Course 1) taught by Drs. Bintang Hanggoro Putra, M.Hum. The students feel lucky because they get the materials directly from the dance creator.

The basic motions of Denok dance is based on Surakarta dance style which is the classical dance in Central Java, but Denok dance developed to be more agile and dynamic. So the dance is classified as type of traditional creation dance. The movements of the feet and hands that go ups and downs in Denok dance represent the geographical conditions of Semarang which are highlands and lowlands. The dance structure is divided into 3 parts following its melody form and the rhythm pattern of the song. Mr. Bintang named each part as Part A, Part B, and Part C. Among the various motions there is a connecting motion called "sendi" with a hand motif called "ngincup". Ngincup means the meeting of the thumb and index finger, but not sticking together while the other finger is straight to the side. The types of movements that are typical in the Denok dance consist of jalan tepak, ngeyek, and ngondhek. The characteristic of the movements needs to be observed by anyone who learns this dance. 


\subsection{Denok Dance Online Learning: No Longer an Option}

Covid-19 has changed the dance learning model. Before the pandemic, online learning was an alternative. Now, it is an obligation. Lecturers should be more flexible in choosing the platform used in learning [11]. Corus revealed that an educator needs to have the ability to network, both technologically and socially, or what is called "The Networked Educator" [5].

UNNES urges all learning activities to be done online. UNNES facilitates an LMS called Elena as a medium of the learning activities. Through the application, lecturers can upload learning materials and evaluations in the form of documents, photos, videos, and audio. The facilities provided are able to bridge the needs of lecturers to communicate with students, upload material, design quizzes and assignments, record attendance, conduct written and oral discussions, and many more. Lecturers of UNNES, including Mr. Bintang has to adapt in order to know and learn about Elena, and so with the students. Various student responses of course appeared. Some were shocked (Javanese say 'gumunan') and felt unprepared. Some were ready and immediately adapted to all existing abilities and facilities. The point is not everyone is ready for change. The creative teachers have ability to make the most of every situation. They have a receptivity to change that allows them to greet new opportunities with glee rather than panic. They are curious [12].

Based on the data obtained through UPT TIK UNNES, the data on the use of Elena as of April 27, 2020 for the Dance Education Study Program, only about $22.55 \%$ of the class used the app. It means that not all of the lecturers use Elena in classroom learning. Broadly speaking, there are two main factors behind this, namely the human resource factor and the Elena's accessibility factor. Most of the lecturers and students are still confused or technologically illiterate in using the application even though there is a guide distributed by UPT TIK. Next is the accessibility factor that is not optimal and is still being improved, especially students who live outside the region. They sometimes experience problems in accessing Elena.

In the online learning of Denok dance, Mr. Bintang has not utilized Elena to its full potential. The material has been uploaded to the application. However, learning activities are mostly done through Google Classroom, Zoom, and a WhatsApp group. Based on a survey through questionnaires, one student said,

"On the Zoom meeting, we can do dance practice with lecturers. The lecturers can also provide materials and fix the dance movements through video teleconferences rather than just give instruction through a WhatsApp group. In addition, Google Classroom is very supportive for collecting practical assignments."

In general, Denok dance online learning that was done in the even semester of 2019/2020 could take place. The discussion about the adaptation strategies carried out by the lecturer in choosing learning method is described in the next discussion.

\subsection{Adaptation Strategy of Semarangan Dance Learning Method}

The learning goal of Tari Pesisiran Jawa Tengah I (Central Java Coastal Dance Course I) is that students can understand and practice Central Java regional dance material both for boys and girls. One of the dances learned is the Denok dance from Semarang. The duration of the dance is about four minutes and the movement techniques are not too difficult, but they have distinctive features. The spirit of learning dance is the physical activity carried out by lecturers and students.

Dance learning has important components that are interrelated to achieve learning goals. One of the components discussed in this study is the learning method. According to Djamrah [13], the basic consideration for the teaching method selection is based on the following factors: 
1) Goals oriented 2) Individual differences of students 3) The educators' ability 4) Characteristics of learning materials 5) Class situation 6) Adequate facilities 7) Strengths and weaknesses of the method. The following explains how the selection of Semarangan dance learning method during the Covid-19 outbreak towards the situation in the classroom, material that is being taught, and completeness of the facility.

First, in contrast to offline lectures, online lectures make learning space and time to be more open [14]-[16]. The lecturer uploads the Denok dance learning video to Google Classroom and Elena. The students learn by opening and studying the video anywhere and anytime. When technology and information were not as sophisticated as now, lecturers were the only source of learning so face-to-face activities with lecturers in class were an opportunity not to be missed. Now, students can repeatedly observe in detail the dance movement techniques taught by the lecturer through a video. There are two types of video uploaded. The video of part-by-part dance demonstrations and the lecturer's review video. Students learn based on video demonstrations. They also send their learning results in the form of videos uploaded to Google Classroom. At the next meeting, the lecturer gives a review based on the video uploaded by the students. The lecturer explains in which part they made mistakes and gives examples of the correct motion. Based on this, the lecturer has adapted to the current situation through the use of information technology in the form of the ability to create learning media (videos) and master distance learning platforms.

Second, the material taught is a dance practice material so the lecturer uses demonstration method complete with the explanations. Demonstration is carried out in detail on every motion such as feet, body, hands, and head motions. Then, it is followed by repetition using accompaniment. Although there are a lot of videos of Denok dance on the internet, it is not right if the lecturer does not provide the correct signs. Many of the videos do not match the original motions. The uploaded video is a performance recording during the show not a learning video. This is why students need to be careful in imitating the motions. In this case, lecturer tries to optimize the video like a digital laboratory. Denok dance has various distinctive motions namely ngeyek, ngondhek, and genjot. All of them have special techniques that the students need to master. During the learning process, lecturer has classically emphasized both in the learning and evaluation videos at each meeting. As revealed by Fadlilah that videos can facilitate students' learning needs which include visual, auditive, and kinesthetic aspects [17]. The students become more enthusiastic about learning if the videos displayed contain systematic, gradual explanations, and clear instructions.

Third, complete facilities. The lecturer has identified the complete facilities that are owned by him, the facilities provided by the campus, as well as the facilities owned by students. Therefore, lecturer chooses to use collaborative learning method. The lecturer uses more than one learning method by utilizing several learning platforms. The lecturer does not only upload the material through Elena, but also on Google Classrooms. Just in case there are students who experience difficulties accessing the Elena. Communication with students is carried out through a WhatsApp group. WhatsApp is easily accessed and is considered to be more familiar to various backgrounds of Indonesians. A WhatsApp group is used as a forum for communication, question and answer, and discussion with the students. If there are things which are unclear, the lecturer gives the opportunity for students to ask questions through the application.

Based on that phenomenon, the researchers observe the materials being taught, the completeness of facilities, and the learning methods used by the lecturer after adapting to the current situation. The lecturer divides materials into four meetings. The first meeting contains the Denok dance synopsis and the dance practice part A. In the second meeting, the lecturer makes a review of Part A's assignment and then followed by Part B. The third meeting is Part 
B motions' review and dance practice Part C. In the fourth meeting, the students do all part of the dance using accompaniment. The adaptation used by the lecturer in the Denok dance learning method is as follows: a) Use collaborative method. It combines several methods in one meeting by using more than one learning platform; b) Reduce lecture method. The lecturer makes important points in a power point video uploaded to Elena and Google Classroom; c) The demonstration method is still used, but in the form of videos. It minimizes direct virtual meeting with the students through Zoom meeting. Zoom is only used in the urgent situation. The students can repeatedly play the videos whenever and wherever. The videos are divided into several parts according to the material per meeting; d) The drill method is done indirectly by assigning the students to send the videos of their learning outcomes of Denok dance. This assignment make the students practice repeatedly until they get good results; e) The lecturers keep using the question and answer method by giving the students opportunity to ask through the comment section in the Google Classroom or WhatsApp group. The question and answer can be done between students to see their activeness and level of understanding of the materials. Peer-review that is carried out online can increase positive feedback [18].

Based on the result of a survey of fifteen students participating in Denok dance learning, $62.5 \%$ of the students strongly agree that the learning method used by the lecturer can support the achievement of learning goals and $50 \%$ of the students feel that the method is easily accepted. These results indicate that in general, the method is acceptable and facilitates the students to learn about the dance.

\subsection{Opportunities and Obstacles in the Online Learning of Semarangan Dance}

Online learning has obstacles and challenge. Opportunities in the online dance learning in a bold way can work well because of the availability of the platforms that are easily accessed and bridge the needs of dance learning. Lecturers can use several platforms that are considered effective and efficient [19]. UPT TIK UNNES continues to strive to improve the system on Elena in order to facilitate the needs of the lecturers, students, and university leaders. Support from the institutions and the government is essential in optimizing online learning.

Obstacles in the online dance learning include the availability of internet data as well as the facilities owned by the students. Students have to be smart in finding the cheap cellular telecommunication operators that reach the internet signal in where they live. Not all of the students have adequate facilities. Some of them find it difficult to save their video recordings because their phones are running out of storage. The next obstacle is to deal with the characteristics of the students who are inactive in the learning process. Disciplinary control through assignments can be done through the system. However, lecturers need to use a humanist approach to determine the condition of each student.

Hidayati and Putra said that the students feel dissatisfied with online learning provided by the lecturer. Based on the data, the level of satisfaction reduced in education, and the students do not have a learning process but should do the tasks. The responses of lecturers in online learning are slow [20]. Based on that research, online learning is difficult to accommodate the different characteristics and competencies of students. In addition, lecturers' evaluation towards student movements can only be done either through the writing, audio, or video but cannot directly touch certain parts of the body which are not right in doing the movements. It is difficult for students to make corrections and even not to realize their mistakes. 


\section{Conclussion}

Covid-19 outbreak has forced Semarangan dance learning in UNNES to be done online. However, it creates opportunities for the lecturers to be creative to adapt by formulating the appropriate learning method to achieve learning goals. Based on several considerations in choosing learning method, lecturer used collaborative learning which utilize various learning platforms such as Elena, Google Classroom, WhatsApp group, and Zoom. Lecturers make videos which contain lesson materials, evaluations, and assignments to be shared with the students. Lecturers and the institution continue to strive to optimize online learning during this pandemic.

Acknowledgments. I am particulary grateful to the Faculty of Languages and Arts, Universitas Negeri Semarang who have funded this research through the faculty's research program.

\section{References}

[1] Jazuli M. 2002. Metode dan Teknik Pengajaran Tari. Harmon J Arts Res Educ. 3(2).

[2] Gayle Kassing, Danielle Mary Jay. 2003. Dance Teaching Methods and Curriculum Design. Human Kinetics.

[3] Huddy A, Stevens K. 2011. The Teaching Artist: a model for university dance teacher training. Res Danc Educ [Internet]. 2011 Jul;12(2):157-71. Available from: http://www.tandfonline.com/doi/abs/10.1080/14647893.2011.579596

[4] Duţă N, Martínez-Rivera O. 2015. Between Theory and Practice: The Importance of ICT in Higher Education as a Tool for Collaborative Learning. Procedia - Soc Behav Sci [Internet]. 2015 May;180:1466-73. Available from: https://linkinghub.elsevier.com/retrieve/pii/S1877042815016407

[5] Lindberg O, Olofsson A. J. Ola Lindberg, Anders D. 2010. Olofsson-Online Learning Communities and Teacher Professional Development_ Methods for Improved Education Delivery (Premier Reference Source)- Information Science Reference (.pdf.

[6] Li Z, Zhou M, Teo T. 2018. Mobile technology in dance education: a case study of three Canadian high school dance programs. Res Danc Educ [Internet]. 2018 May 4;19(2):18396. Available from: https://doi.org/10.1080/14647893.2017.1370449

[7] W. Creswell J. 2009. Research Design: Qualitative, Quantitative, and Mixed Method Approaches. Sage. London: Sage;

[8] Sugiyono. 2008. Metode penelitian pendidikan: (pendekatan kuantitatif, kualitatif dan R $\&$ D) [Internet]. Bandung: Alfabeta; 2008. Available from: https://books.google.co.id/books?id=0xmCnQAACAAJ\&dq=Sugiyono\&hl=id\&sa=X\&v ed=0ahUKEwiZjsb-o5neAhVEu48KHeYpDioQ6AEIJzAA

[9] Septiyan DD. 2016. Eksistensi Kesenian Gambang Semarang Dalam Budaya Semarangan. J Pendidik dan Kaji Seni [Internet]. 2016;1(2):157-9. Available from: https://jurnal.untirta.ac.id/index.php/JPKS/article/view/1027

[10] Tristiani VD, Lanjari R. 2019. Nilai Estetika Tari Gambang Semarang pada Komunitas Gambang Semarang Art Company. J Seni Tari.;8(2):198-204.

[11] Callo EC, Yazon AD. 2020. Exploring the Factors Influencing the Readiness of Faculty and Students on Online Teaching and Learning as an Alternative Delivery Mode for the New Normal.;8(8):3509-18.

[12] Lafever MD. 2013. Creative Teaching Methods. David C Cook;

[13] Djamarah SB. 2005. Guru dan Anak Didik dalam Interaksi Anak Didik. Jakarta: Rineka 
Cipta;

[14] Noam ELIM. Media and Digital Management. Palgrave macmillan;

[15] Van Peer W, Zyngier S, Klinger K, Tosheff L. Literary education and Digital Learning: methods and technologies for Humanities Studies Library of C [Internet]. Available from: http://www.igi-global.com

[16] Duff A. 2003. Higher Education Teaching: A Communication Perspective. Act Learn High Educ.

[17] Fadlilah N, Sulisworo D, Maruto G. 2020. The Effectiveness of a Video-based Laboratory on Discovery Learning to Enhance Learning Outcomes.;8(8):3648-54.

[18] Hsia L-H, Huang I, Hwang G-J. 2016. Effects of different online peer-feedback approaches on students' performance skills, motivation and self-efficacy in a dance course. Comput Educ [Internet]. 2016 May;96:55-71. Available from: https://linkinghub.elsevier.com/retrieve/pii/S0360131516300240

[19] Garnar AW. 2018. Educational Technology. Spaces for the Future. Singapore: Springer; 82-91 p.

[20] Hidayati D, Saputra WA. 2020. Implementation of Online Learning during the Covid-19 Epidemic in Indonesia: Assessment of Higher Education Students 'Use and Implementation of Online Learning Technology. Univers J Educ Res. 2020;8(10):4514-9. 